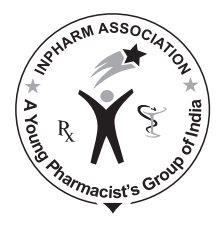

\title{
Synthesis of Tryptoline-3-Carboxylic Acid Derivatives A Novel Antidiabetic Agent
}

\author{
Choudhary AN, Kohli MS', Kumar A, Joshi A \\ Department of Pharmaceutical Sciences, Bhimtal Campus, Bhimtal, Kumaun University, Nainital 263136, \\ Uttrakhand, ${ }^{1}$ Ranbaxy Research Ltd., Gurgoan, Haryana-122002, India
}

Address for correspondence: Dr.A. N. Choudhary; E-mail: alka_pharma@rediiffmail.com

\begin{abstract}
The compounds, 2-(methylsulfonyl)-1,2,3,4-tetrahydro-9H-pyrido[3,4-b]indole-3-carboxylic acid (DM3), 2-(phenylsulfonyl)-1,2,3,4-tetrahydro-9H-pyrido[3,4-b]indole-3-carboxylic acid $\left(\mathrm{DM}_{4}\right)$, and 2-( $p$-toluenesulfonyl)1,2,3,4-tetrahydro-9H-pyrido[3,4-b]indole-3-carboxylic acid $\left(\mathrm{DM}_{5}\right)$ were synthesized by coupling of 1,2,3,4-tetrahydro-9H-pyrido[3,4-b]indole-3-carboxylic acid $\left(\mathrm{DM}_{2}\right)$ with methanesulfonyl chloride, benzenesulfonyl chloride, and toluenesulfonyl chloride, which in turn, was synthesized by dissolving dilute aqueous ammonia with 2-( $N$-hydroxy methyl amino)-indol-3-yl-propanoic acid $\left(\mathrm{DM}_{1}\right)$ which is the reaction product of I-tryptophan and formalin. All the intermediates and title compounds were characterized by physical, chemical, analytical, and spectral data. All the title compounds have been screened for in vivo antidiabetic activity in streptozotocininduced diabetic rats, and serum glucose was estimated spectrophotometrically at $505 \mathrm{~nm}$ by glucose oxidase/ peroxidase method. Compound $\mathrm{DM}_{5}$ showed potent antidiabetic activity.
\end{abstract}

Key words: Antidiabetic agents, 2-( $\mathrm{N}$-hydroxymethyl amino)-indol-3-yl-propanoic acid, 1,2,3,4-tetrahydro- $9 \mathrm{H}$ pyrido [3,4-b] indole-3-carboxylic acid, Peroxisome proliferator-activated receptorg (PPAR- $\gamma$ ) agonists

\section{INTRODUCTION}

Diabetes mellitus is a major health concern, especially in the urban world. ${ }^{[1]}$ Over $90 \%$ of the diabetes mellitus patients are type- 2 patients. ${ }^{[2]}$ Type- 2 diabetes mellitus is characterized by insulin resistance and cardiovascular dysmetabolic syndrome. ${ }^{[3]}$ The conventional therapy of

\begin{tabular}{|l|l|}
\hline \multicolumn{2}{|c|}{ Access this article online } \\
\hline Quick Response Code: & \\
\hline & Website: \\
& www.jyoungpharm.in \\
& \\
\hline
\end{tabular}

type-2 diabetes mellitus has not been satisfactory as it is not successful in treating associated cardiovascular risk factors, which is the main cause of morbidity. ${ }^{[4]}$ The current trend is therefore, to make therapy better by choosing appropriate combination of available drugs. A parallel search for newer drugs is also being made.

Thiazolidine-2,4-diones are the class of oral hypoglycemic agents which increase insulin sensitivity at target tissues such as liver and skeletal muscles. In addition, it also improves the markers of cardiovascular risk factors by decreasing the free fatty acids and altering the lipoprotein metabolism. ${ }^{[5]}$ Thiazolidine-2,4-diones act on peroxisome proliferators activating receptor- $\gamma$ (PPAR- $\gamma$ ) receptors which regulate the gene expression mainly in the adipose tissues. $^{[-8]}$ Rosiglitazone and pioglitazone molecules from 
the class of thioglitazone available in the market are showing severe adverse effects. ${ }^{[9,10]}$

A survey of literature revealed that replacement of the thiazolidine-2,4-dione ring by various acidic groups such as $\alpha$-heteroatom-substituted carboxylic acids and $\alpha$-carbonsubstituted carboxylic acids can results in qualitative and quantitative changes in the activity, ${ }^{[11-13]}$ which prompted us to undertake the synthesis of various new derivatives with the aim of having improved activity and less toxicity.

\section{MATERIALS AND METHODS}

The melting points were recorded in open sulphuric acid or oil bath using thermometer and were uncorrected. IR spectra were recorded using Hitachi 270-30 infrared and Bruker Vector 22 spectrophotometers using $\mathrm{KBr}$ pellet techniques. ${ }^{1} \mathrm{H}-\mathrm{NMR}$ spectrum was recorded using DMSO-d ${ }_{6}$ on Bruker Avance DPX-200 at $300 \mathrm{MHz}$, and their chemical shifts are recorded in $\delta$ (parts per million) units with respect to tetramethyl silane (TMS) as an internal standard. Atmospheric pressure ionization (API) mass spectra were recorded on Bruker Ion Trap Esquire 3000 spectrometer with the ionization potential 3000 V. Progress of the reactions was monitored using TLC, performed on aluminum plates precoated with silica gel-G, using chloroformmethanol (92:8) as the solvent systems, and the spots were visualized by exposure to iodine vapors. The physical constants of the title compounds are reported in Table 1.

Procedure for the preparation of 2-( $N$-hydroxymethyl amino)-indol-3-yl-propanoic acid ( $\left.\mathrm{DM}_{1}\right)$

In a $250-\mathrm{mL}$ conical flask, $5 \mathrm{~g}$ (0.0245 M) of l-tryptophan was dissolved in $120 \mathrm{~mL}$ of water. To this, $20 \mathrm{~mL}$ formalin was added and the mixture was incubated at $38^{\circ} \mathrm{C}$ for 6 h. The colorless, crystalline, but rather granular solid that had then separated was collected, washed with cold water, and dried in vacuum. The crude product was recrystallized from hot water.

IR (KBr) (cm $\left.{ }^{-1}\right):$ 3600-3400 (m) broad O-H stretching,
3300 (m) N-H stretching, 3099 (m) aromatic C-H stretching (asymmetric), $3056(\mathrm{~m})$ aromatic $\mathrm{C}-\mathrm{H}$ stretching (symmetric), 2989 (m) aliphatic $\mathrm{C}-\mathrm{H}$ stretching (asymmetric), $2852(\mathrm{~m})$ aliphatic $\mathrm{C}-\mathrm{H}$ stretching (symmetric), 1680 (s) carbonyl stretching 1620, 1552, 1447 (m) skeleton in plane vibrations $\mathrm{C}=\mathrm{C}, 1408-1425$ (s) $\mathrm{C}=\mathrm{C}$ and $\mathrm{C}=\mathrm{N}$ ring stretching, $750(\mathrm{~m}) \mathrm{N}-\mathrm{H}$ wagging, 741 (s) out of plane $\mathrm{C}=\mathrm{C}$ bending.

${ }^{1} \mathrm{H}-\mathrm{NMR}$ (DMSO-d ${ }^{6}, 300 \mathrm{MHz}$ ), $\delta$ (ppm): 7.36-7.45 (m, $4 \mathrm{H}, \mathrm{ArH}$ ), 7.10 (s, $1 \mathrm{H}, \alpha$ proton of indole ring), 3.70-3.80 (s, $1 \mathrm{H}$, aromatic $\mathrm{N}-\mathrm{H}, \mathrm{D}_{2} \mathrm{O}$ exchangeable), $2.80\{\mathrm{~d}, 2 \mathrm{H}$, $\left.-\mathrm{CH}_{2}\left(J_{\text {vic }}=7.2\right)\right\}, 3.88\left\{\mathrm{t}, 1 \mathrm{H},-\mathrm{CH}\left(J_{\text {vic }}=7.2\right)\right\}, 11.00(\mathrm{~s}$, $1 \mathrm{H}, \mathrm{COOH}), 2.10$ (s, $1 \mathrm{H}, \mathrm{NH}, \mathrm{D}_{2} \mathrm{O}$ exchangeable), 4.60 $\left(\mathrm{s}, 2 \mathrm{H},-\mathrm{CH}_{2}\right), 4.10$ (s, $\left.1 \mathrm{H}, \mathrm{OH}\right)$.

Mass spectra: Molecular ion peak $\mathrm{M}$ at $m / e$ e 234 (23.8\%), $[\mathrm{M}-(\mathrm{OH})]^{+}$and $\left[\mathrm{M}-\left(\mathrm{H}_{2} \mathrm{O}\right)\right]^{+}$shows peak at $\mathrm{m} / e 217$ (32.4\%), $216(100 \%)$. The other important ions are at $m / e$ 190 (10.5\%), 158 (8.4\%), 157 (11.8\%), 156 (15.3), 144 $(10.8 \%), 117(18.6 \%)$, and $91(8.5 \%)$.

Procedure for the preparation of 1,2,3,4-tetrahydro$\mathbf{9 H}$-pyrido [3,4-b] indole-3-carboxylic acid $\left(\mathbf{D M}_{2}\right)$ : In a $250-\mathrm{mL}$ conical flask, $150 \mathrm{~mL}$ of dilute aqueous ammonia was placed and $5 \mathrm{~g}(0.0214 \mathrm{M})$ of $\alpha$-hydroxymethylamino$\beta$-3-indolylpropionic acid $\left(\mathrm{DM}_{1}\right)$ was added and dissolved. Then, this solution was refluxed for $3 \mathrm{~h}$ and concentrated to a small volume. The white-to-cream colored crystals obtained were given charcoal treatment and filtered by suction, washed with cold water and dried at $80^{\circ} \mathrm{C}$. The product was obtained in colorless leaflets and was purified by recrystallization from hot water.

IR (KBr) (cm $\left.{ }^{-1}\right): 3650-3300(\mathrm{~m})$ broad O-H stretching, $3350(\mathrm{~m}) \mathrm{N}-\mathrm{H}$ stretching, $3100(\mathrm{~m})$ aromatic $\mathrm{C}-\mathrm{H}$ stretching (asymmetric), $3056(\mathrm{~m})$ aromatic $\mathrm{C}-\mathrm{H}$ stretching (symmetric), 2990 (m) aliphatic $\mathrm{C}-\mathrm{H}$ stretching (asymmetric), $2850(\mathrm{~m})$ aliphatic $\mathrm{C}-\mathrm{H}$ stretching (symmetric), 1690 (s) carbonyl stretching 1600, 1582, 1450 (m) skeleton in plane vibrations $\mathrm{C}=\mathrm{C}, 1410-1430(\mathrm{~s}) \mathrm{C}=\mathrm{C}$ and $\mathrm{C}=\mathrm{N}$ ring stretching, $760(\mathrm{~m}) \mathrm{N}-\mathrm{H}$ wagging, 752 (s) out of plane $\mathrm{C}=\mathrm{C}$ bending.

Table 1: Physical constants of intermediates and title compounds

\begin{tabular}{|c|c|c|c|c|c|c|}
\hline Compound code & Molecular formula & Molecular weight & $\begin{array}{c}\text { Yield, } \\
\%\end{array}$ & $\begin{array}{c}\text { Melting point } \\
\left({ }^{\circ} \mathrm{C}\right)\end{array}$ & $\begin{array}{c}\text { Solvent system } \\
\text { chloroform:methanol }\end{array}$ & $R_{\mathrm{f}}$ values \\
\hline $\mathrm{DM}_{1}$ & $\mathrm{C}_{12} \mathrm{H}_{12} \mathrm{~N}_{2} \mathrm{O}_{3}$ & 234.32 & 75 & $230-231$ & $92: 8$ & 0.50 \\
\hline $\mathrm{DM}_{2}$ & $\mathrm{C}_{12} \mathrm{H}_{12} \mathrm{~N}_{2} \mathrm{O}_{2}$ & 216.23 & 80 & $312-313$ & $92: 8$ & 0.72 \\
\hline $\mathrm{DM}_{3}$ & $\mathrm{C}_{12} \mathrm{H}_{14} \mathrm{~N}_{2} \mathrm{O}_{4} \mathrm{~S}$ & 294.32 & 70 & $240-242$ & $92: 8$ & 0.62 \\
\hline $\mathrm{DM}_{4}$ & $\mathrm{C}_{18} \mathrm{H}_{16} \mathrm{~N}_{2} \mathrm{O}_{4} \mathrm{~S}$ & 356.39 & 78 & $262-263$ & $92: 8$ & 0.69 \\
\hline $\mathrm{DM}_{5}$ & $\mathrm{C}_{19} \mathrm{H}_{18} \mathrm{~N}_{2} \mathrm{O}_{4} \mathrm{~S}$ & 370.42 & 74 & $274-275$ & $92: 8$ & 0.67 \\
\hline
\end{tabular}


${ }^{1} \mathrm{H}-\mathrm{NMR}$ (DMSO-d ${ }^{6}, \mathbf{3 0 0} \mathrm{MHz}$ ), $\boldsymbol{\delta}$ (ppm): 7.10-7.56 (m, 4H, ArH), 3.70-3.80 (s, $1 \mathrm{H}$, aromatic $\mathrm{N}-\mathrm{H}, \mathrm{D}_{2} \mathrm{O}$ exchangeable), $2.80\left\{\mathrm{~d}, 2 \mathrm{H},-\mathrm{CH}_{2}\left(J_{\text {vic }}=7.2\right)\right\}, 3.88$ $\left\{\mathrm{t}, 1 \mathrm{H}, \mathrm{CH}\left(J_{\text {vic }}=7.2\right)\right\}, 11.00(\mathrm{~s}, 1 \mathrm{H}, \mathrm{COOH}), 2.10$ (s, $1 \mathrm{H}, \mathrm{NH}$ of piperidine ring, $\mathrm{D}_{2} \mathrm{O}$ exchangeable), 4.10 $\left(\mathrm{s}, 2 \mathrm{H}, \mathrm{CH}_{2}\right)$.

Mass spectra: Molecular ion peak M at $m / e 216(100 \%)$, $[\mathrm{M}-(\mathrm{OH})]^{+}$and $\left[\mathrm{M}-\left(\mathrm{C}_{2} \mathrm{H}_{2}\right)\right]^{+}$shows peak at $\mathrm{m} / \mathrm{e} 199$ (18.4\%), $190(27.2 \%)$. The other important ions are at m/e 177 (19.7\%), 144 (14.3\%), 118 (5.8\%), 117 (20.5\%), $91(6.2 \%), 91(5.8 \%)$.

Procedure for the preparation of 2-(methylsulfonyl)$1,2,3,4$-tetrahydro- $9 H$-pyrido $[3,4-b]$ indole-3carboxylic acid $\left(\mathrm{DM}_{3}\right)$

Treated $3 \mathrm{~g}(0.01389 \mathrm{M})$ of the amine $\left(\mathrm{DM}_{2}\right)$ with 50 $\mathrm{mL}$ of $10 \%$ sodium hydroxide solution and $2 \mathrm{~mL}(3.5 \mathrm{~g}$, $0.0303 \mathrm{M}$ ) of methanesulfonyl chloride was added in small proportions. The reaction mixture was stirred vigorously for $30 \mathrm{~min}$ and warmed it slightly with continued shaking. When the odor of methanesulfonyl chloride was dissipated, the mixture was cooled in an ice bath. As oil separated, crystallization was induced by rubbing the inner wall of the beaker with the glass rod in an ice bath. Any solid produced should be separated by filtration; and the crude product was recrystallized from dilute ethanol to give pure $\mathrm{DM}_{3}$ as light brown crystals.

IR (KBr) (cm $\left.{ }^{-1}\right)$ : 3600-3400 (Broad O-H stretching), 3300 (N-H stretching), 3099 (aromatic $\mathrm{C}-\mathrm{H}$ stretching asymmetric), 3056 (aromatic $\mathrm{C}-\mathrm{H}$ stretching symmetric), 2989 (aliphatic C-H stretching asymmetric), 2852 (aliphatic C-H stretching symmetric), 1680 (carbonyl stretching), 1620, 1552, 1447 (skeleton in plane vibrations $\mathrm{C}=\mathrm{C}), 748(\mathrm{~N}-\mathrm{H}$ wagging), 741 (s) out of plane $\mathrm{C}=\mathrm{C}$ bending, 1330 (s) $\mathrm{SO}_{2}$ stretching asymmetric, 1120 (s) $\mathrm{SO}_{2}$ stretching symmetric, 560 (s) $\mathrm{SO}_{2}$ rocking, 530 (s) $\mathrm{SO}_{2}$ scissoring.

${ }^{1} \mathrm{H}-\mathrm{NMR}$ (DMSO-d $\left.{ }^{6}, 300 \mathrm{MHz}\right), \delta$ (ppm): 7.10-7.40 (m, 4H, ArH), 3.70-3.80 (s, $1 \mathrm{H}$, aromatic $\mathrm{N}-\mathrm{H}, \mathrm{D}_{2} \mathrm{O}$ exchangeable), $2.80\left\{\mathrm{~d}, 2 \mathrm{H},-\mathrm{CH}_{2}\left(J_{\text {vic }}=7.2\right)\right\}, 3.88\{\mathrm{t}$, $\left.1 \mathrm{H},-\mathrm{CH}\left(J_{\text {vic }}=7.2\right)\right\}, 11.00(\mathrm{~s}, 1 \mathrm{H}, \mathrm{COOH}), 2.90(\mathrm{~s}, 3 \mathrm{H}$, $\left.-\mathrm{SO}_{2} \mathrm{CH}_{3}\right), 3.80-3.85\left(\mathrm{~m}, 2 \mathrm{H},-\mathrm{CH}_{2}\right)$.

Mass spectra: Molecular ion peak M at $m / e ~ 294$ (43.9\%), $[\mathrm{M}-(\mathrm{OH})]^{+}$shows peak at $m / e 277(26.2 \%)$. The other important ions are at $m / e 249$ (10.8\%), 216 (100\%), 144 (12.2\%), 118 (6.4\%), 117 (20.5\%), 107 (6.2\%), 91 (16.5\%), $79(8.4 \%)$.
Procedure for the preparation of 2-(phenylsulfonyl)1,2,3,4-tetrahydro-9H-pyrido [3,4-b] indole-3carboxylic acid $\left(\mathrm{DM}_{4}\right)$

To a $100-\mathrm{mL}$ round bottom flask was added $3 \mathrm{~g}$ (0.01389 M) of amine $\left(\mathrm{DM}_{2}\right), 20 \mathrm{~mL}$ of dry pyridine, and $2 \mathrm{~mL}$ $(2.75 \mathrm{~g}, 0.01559 \mathrm{M})$ of benzene sulfonylchloride. The reaction mixture was refluxed for $2 \mathrm{~h}$ on heating mantle and poured into crushed ice to give a light-brownish solid. As oil separated, crystallization was induced by rubbing the inner wall of the beaker with the glass rod in an ice bath. Any solid produced should be separated by filtration, and the crude product was recrystallized from dilute ethanol to give pure $\mathrm{DM}_{4}$ as light brown crystals.

IR (KBr) ( cm $\left.^{-1}\right)$ : 3600-3400 (m) (broad O-H stretching), 3300 (m) (N-H stretching), 3099 (m) (aromatic C-H stretching asymmetric), 3056 (m) (aromatic C-H stretching symmetric), 2989 (m) (aliphatic C-H stretching asymmetric), 2852 (m) (aliphatic C-H stretching symmetric), 1680 (s) (carbonyl stretching), 1620, 1552, 1447 (m) (skeleton in plane vibrations $-\mathrm{C}=\mathrm{C}), 1408-1425(\mathrm{~s})(\mathrm{C}=\mathrm{C}$ and $\mathrm{C}=\mathrm{N}$ ring stretching), $750(\mathrm{~N}-\mathrm{H}$ wagging), 741 (s) out of plane $\mathrm{C}=\mathrm{C}$ bending, 1338 (s) $\mathrm{SO}_{2}$ stretching asymmetric, 1118 (s) $\mathrm{SO}_{2}$ stretching symmetric, 565 (s) $\mathrm{SO}_{2}$ rocking, 532 (s) $\mathrm{SO}_{2}$ scissoring.

$\mathrm{H}^{1}$ NMR (DMSO-d $\left.{ }^{6}, 300 \mathrm{MHz}\right), \delta$ (ppm): 7.05-7.10 (m, 4H, ArH), 3.70-3.80 (s, $1 \mathrm{H}$, aromatic $\mathrm{N}-\mathrm{H}, \mathrm{D}_{2} \mathrm{O}$ exchangeable), $2.80\left\{\mathrm{~d}, 2 \mathrm{H},-\mathrm{CH}_{2}\left(J_{\text {vic }}=7.2\right)\right\}, 3.86\{\mathrm{t}$, $\left.1 \mathrm{H},-\mathrm{CH}\left(J_{\text {vic }}=7.2\right)\right\}, 11.00(\mathrm{~s}, 1 \mathrm{H}, \mathrm{COOH}), 7.95(\mathrm{~d}, 2 \mathrm{H}$, o-protons of $\mathrm{ArH}$ with respect to $\mathrm{SO}_{2}$ group), 7.30-7.50 (m, $3 \mathrm{H}, \mathrm{ArH}$ with respect to $\left.\mathrm{SO}_{2}\right), 4.55-4.60\left(\mathrm{~m}, 2 \mathrm{H},-\mathrm{CH}_{2}\right)$.

Mass spectra: Molecular ion peak Mat $m / e 356$ (43.9\%), $[\mathrm{M}-(\mathrm{OH})]^{+}$at $m / e 339(18.8 \%)$. The other important ions are at $m / e 330(21.2 \%), 311(13.5 \%), 216(100 \%), 169$ (16.44\%), 144 (20.54\%), 141 (6.5\%), 118 (22.4\%), 117 (23.7\%), 91 (8.5\%), 77 (9.4\%), 51 (6.2\%)

Procedure for the preparation of 2-( $p$-toluenesulfonyl)1,2,3,4-te trahydro-9H-pyrido [3,4-b] indole-3carboxylic acid $\left(\mathrm{DM}_{5}\right)$

Treated $3 \mathrm{~g}(0.01389 \mathrm{M})$ of the amine $\left(\mathrm{DM}_{2}\right)$ with $50 \mathrm{~mL}$ of $10 \%$ sodium hydroxide solution and $3 \mathrm{~g}(0.01574 \mathrm{M})$ of $p$-toluenesulfonyl chloride was added in small proportions. The reaction mixture was stirred vigorously for $30 \mathrm{~min}$ and warmed it slightly and shaking was continued. When the odor of $p$-toluenesulfonyl chloride was dissipated, the mixture was cooled in an ice bath. As oil started separating, crystallization was induced by rubbing the inner wall of the 
beaker with the glass rod in an ice bath. Any solid produced should be separated by filtration, and the crude product was recrystallized from dilute ethanol to give pure $\mathrm{DM}_{5}$ as light brown crystals.

IR (KBr) cm cm $^{-1}$ 3600-3400 (m) (broad O-H stretching), 3300 (m) (N-H stretching), 3099 (m) (aromatic C-H stretching asymmetric), 3056 (m) (aromatic $\mathrm{C}-\mathrm{H}$ stretching symmetric), 2989 (m) (aliphatic C-H stretching asymmetric), 2852 (m) (aliphatic C-H stretching symmetric), 1680 (s) (carbonyl stretching), 1620, 1552, 1447 (m) (skeleton in plane vibrations $\mathrm{C}=\mathrm{C}), 1408-1425(\mathrm{~s})(\mathrm{C}=\mathrm{C}$ and $\mathrm{C}=\mathrm{N}$ ring stretching), 748 (m) (N-H wagging), 740 (s) out of plane $\mathrm{C}=\mathrm{C}$ bending, 1328 (s) $\mathrm{SO}_{2}$ stretching asymmetric, 1122 (s) $\mathrm{SO}_{2}$ stretching symmetric, 560 (s) $\mathrm{SO}_{2}$ rocking, 532 (s) $\mathrm{SO}_{2}$ scissoring.

${ }^{1} \mathrm{H}-\mathrm{NMR}$ (DMSO-d $\left.{ }^{6}, 300 \mathrm{MHz}\right), \boldsymbol{\delta}$ (ppm): 7.05-7.10 (m, 4H, ArH), 3.70-3.80 (s, $1 \mathrm{H}$, aromatic $\mathrm{N}-\mathrm{H}, \mathrm{D}_{2} \mathrm{O}$ exchangeable), $2.80\left\{\mathrm{~d}, 2 \mathrm{H},-\mathrm{CH}_{2}\left(J_{\text {vic }}=7.2\right)\right\}, 3.88\{\mathrm{t}$, $\left.1 \mathrm{H},-\mathrm{CH}\left(J_{\text {vic }}=7.2\right)\right\}, 11.00(\mathrm{~s}, 1 \mathrm{H}, \mathrm{COOH}), 7.80(\mathrm{~d}, 2 \mathrm{H}$, o-protons of $\mathrm{ArH}$ with respect to $\mathrm{SO}_{2}$ group), 7.30-7.45 (m, $2 \mathrm{H}, m$-protons of $\mathrm{ArH}$ with respect to $\mathrm{SO}_{2}$ group), $2.45\left(\mathrm{~s}, 3 \mathrm{H},-\mathrm{CH}_{3}\right), 4.55-4.62\left(\mathrm{~m}, 2 \mathrm{H},-\mathrm{CH}_{2}\right)$.

Mass spectra: Molecular ion peak M at $m / e 370(44.2 \%)$ and $[\mathrm{M}-(\mathrm{OH})]^{+}$shows peak at $m / e 353(11.9 \%)$. The other important ions are at $m / e ~ 330(21.4 \%), 325(13.9 \%), 216$ (100\%), $183(6.44 \%), 155(20.5 \%), 144(14.2 \%), 118(9.2 \%)$, 117 (22.88\%), 91 (8.5\%), 91 (9.4\%).

\section{Evaluation of antidiabetic activity}

The synthesized compounds were screened for in vivo antidiabetic activity in streptozotocin-induced diabetic rats. After administration of standard drug (pioglitazone) and synthesized compounds $\left(\mathrm{DM}_{1-5}\right)$, serum glucose was estimated spectrophotometrically at $505 \mathrm{~nm}$ by glucose oxidase/peroxidase method using a commercially available kit (Span Diagnostic Ltd, Surat, India).

Concentration of glucose $(\mathrm{mg} / \mathrm{dL})=$ Optical density of test/Optical density of std. $\times 100$.

The results are summarized in Table 2.

\section{RESULTS AND DISCUSSION}

The structures of synthesized compounds were confirmed by thin layer chromatography (TLC), m.p, IR, ${ }^{1} \mathrm{H}-\mathrm{NMR}$, and mass spectrometry (MS) spectral analysis. The compounds $\left(\mathrm{DM}_{3}-\mathrm{DM}_{5}\right)$ were synthesized by the treatment
Table 2: Antidiabetic activity of synthesized compounds against streptozotocin-induced diabetes in rats

\begin{tabular}{lc}
\hline Groups & Blood glucose concentration $(\mathbf{m g} / \mathbf{d L})$ \\
\hline $\mathrm{DM}_{1}$ & 176 \\
$\mathrm{DM}_{2}$ & 179 \\
$\mathrm{DM}_{3}$ & 154 \\
$\mathrm{DM}_{4}$ & 167 \\
$\mathrm{DM}_{5}$ & 145 \\
Control & 118 \\
Streptozotocin treated & 187 \\
Pioglitazone treated & 135 \\
\hline
\end{tabular}

of $l$-tryptophan with formaldehyde which resulted in the formation of an intermediate $\alpha$-hydroxymethylamino- $\beta$ 3 -indolylpropionic acid $\left(\mathrm{DM}_{1}\right)$ which after refluxing with ammonia solution for $3 \mathrm{~h}$ resulted in cyclized product $\mathrm{DM}_{2}$ (Scheme 1). The compound $\mathrm{DM}_{2}$ on further treatment with methanesulfonyl chloride, benzenesulfonyl chloride, and toluenesulfonyl chloride yields different 1,2,3,4-tetrahydro-9H-pyrido[3,4-b]indole-3-carboxylic acid derivatives (Scheme 2). The yield was found to be in range of $70-80 \%$. The title compounds were confirmed by IR spectral data showing characteristic bands at 3650-3300 $\mathrm{cm}^{-1}$ corresponding to $\mathrm{OH}$ stretching, sharp band at 1690 $\mathrm{cm}^{-1}$ indicated the presence of $\mathrm{C}=\mathrm{O}$ group. Compounds $\left(\mathrm{DM}_{3}-\mathrm{DM}_{5}\right)$ were confirmed by stretching at 1330 and 1120 $\mathrm{cm}^{-1}$ due to the presence of the $\mathrm{SO}_{2}$ group. Compounds $\mathrm{DM}_{1}-\mathrm{DM}_{5}$ was confirmed by ${ }^{1} \mathrm{H}-\mathrm{NMR}$ spectral analysis. The NMR proton singlet peak at $\delta 11 \mathrm{ppm}$ and $3.70-3.80$ revealed the presence of carboxylic acid and aromatic $\mathrm{N}-\mathrm{H}$ groups. Further appearance of molecular ion peak $\mathrm{M}$ at $\mathrm{m} / \mathrm{e}$ $294(43.9 \%) 356(43.9 \%)$, and $370(44.2 \%)$ confirmed the structures of compounds $\left(\mathrm{DM}_{3}-\mathrm{DM}_{4}\right)$. The compounds $\mathrm{DM}_{1}$ and $\mathrm{DM}_{2}$ do not significantly decrease blood glucose level in streptozotocin-induced diabetes. Compounds $\mathrm{DM}_{3}$ and $\mathrm{DM}_{4}$ exhibited less activity, whereas compound $\mathrm{DM}_{5}$ i.e., was found to possess better antidiabetic activity.

\section{CONCLUSIONS}

The yield of all 1,2,3,4-tetrahydro-9H-pyrido[3,4-b]indole3 -carboxylic acid derivatives were found to be in the range $70-80 \%$. The purity of compounds was ascertained by meting point and TLC. The assigned structures were further established by IR, ${ }^{1} \mathrm{H}-\mathrm{NMR}$, and mass spectral studies. The antidiabetic activity of the synthesized compounds was screened using streptozotocin-induced diabetes in rats. Pioglitazone was used as a standard drug. Compounds $\mathrm{DM}_{3}$ [2-(methylsulfonyl)-1,2,3,4-tetrahydro$9 H$-pyrido[3,4-b]indole-3-carboxylic acid] and $\mathrm{DM}_{4}$ [2-(phenylsulfonyl)-1,2,3,4-tetrahydro-9H-pyrido[3,4-b] 
Choudhary, et al.: Synthesis of tryptoline-3-carboxylic acid derivatives

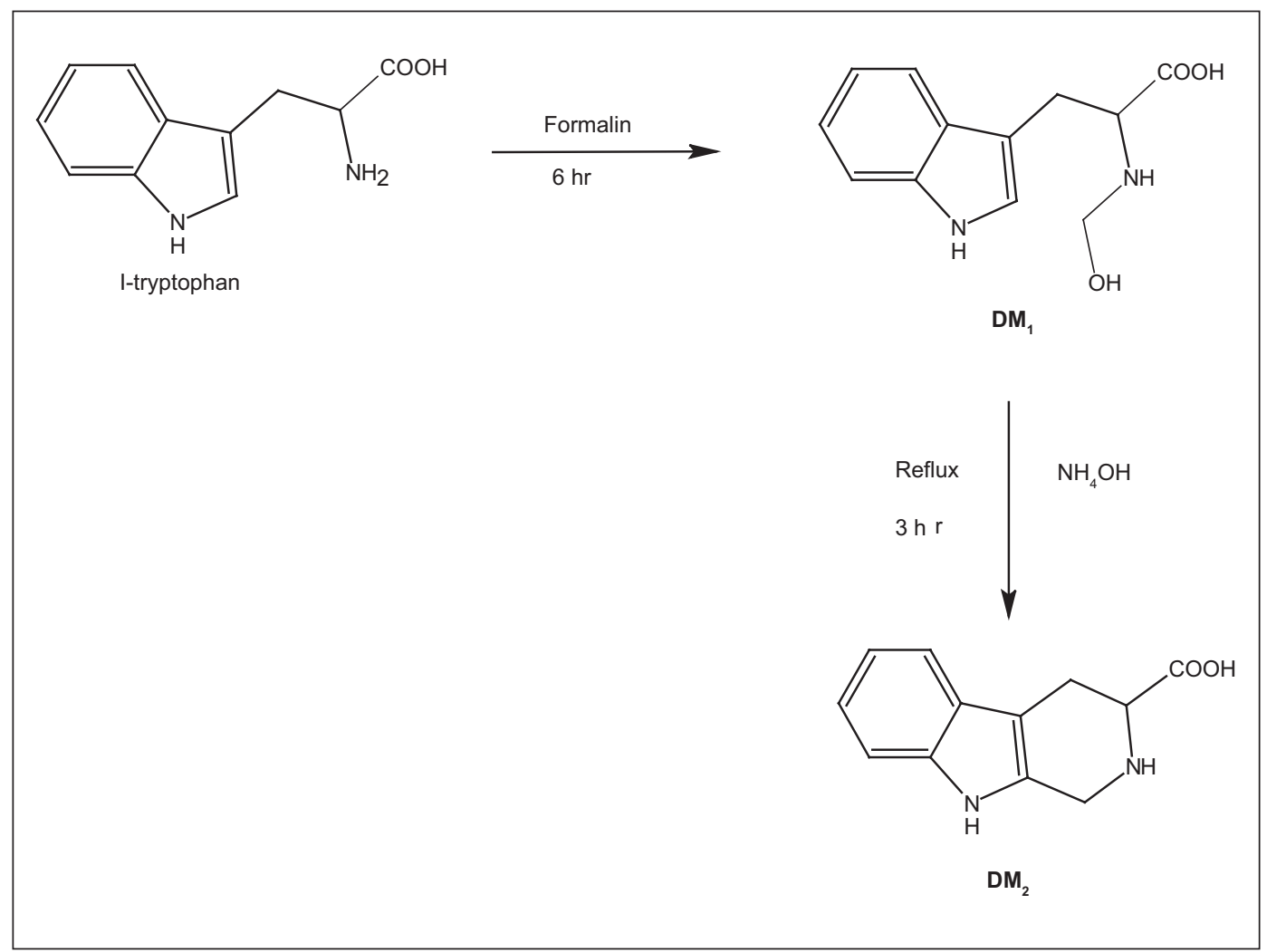

Scheme 1: Synthesis of $\mathrm{DM}_{2}$

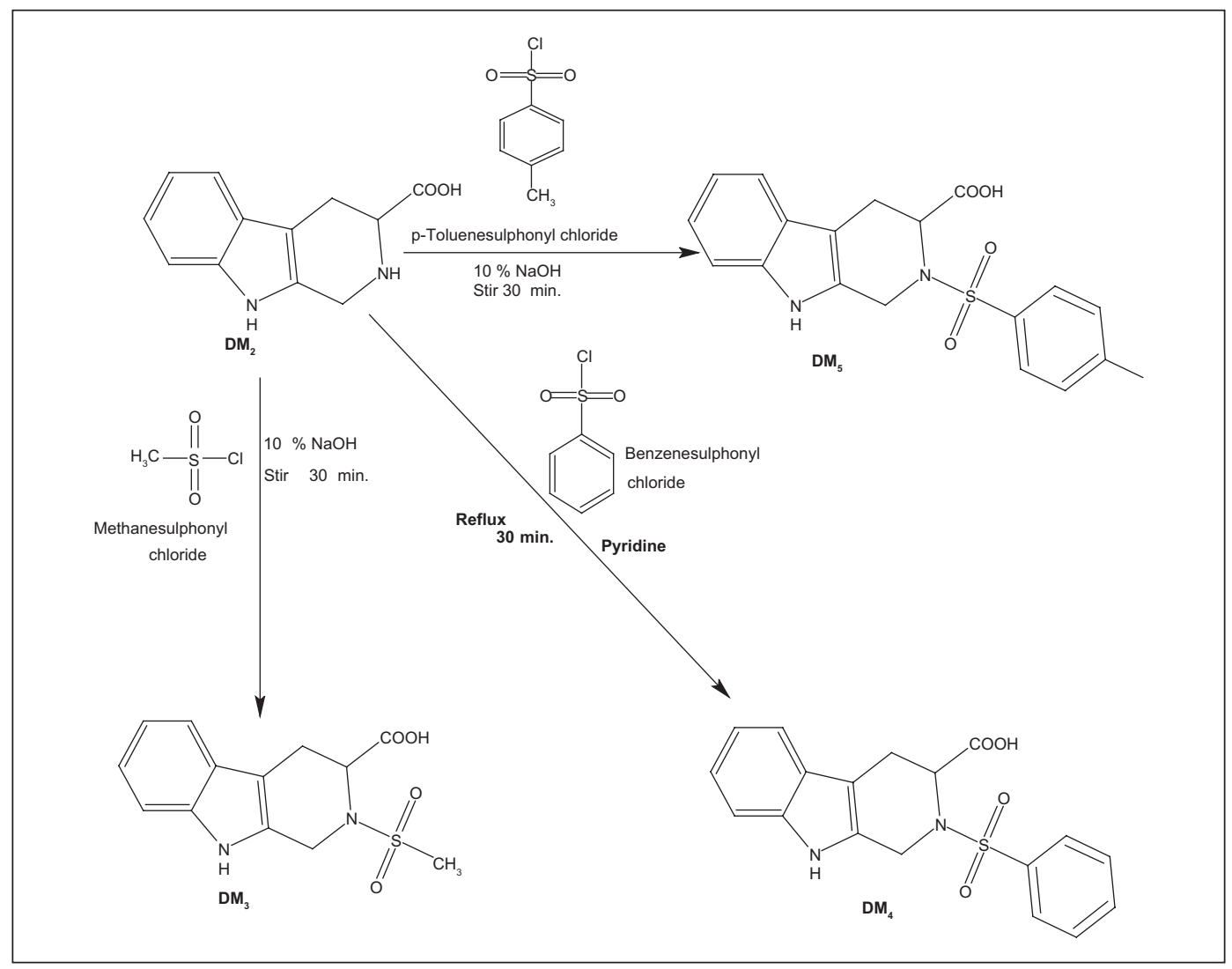

Scheme 2: Synthesis of $\mathrm{DM}_{3}, \mathrm{DM}_{4}$ and $\mathrm{DM}_{5}$ 
indole-3-carboxylic acid] showed moderate activity, whereas compound $\mathrm{DM}_{5}$ [2-( $\not$-toluenesulfonyl)-1,2,3,4-tetrahydro$9 H$-pyrido[3,4-b]indole-3-carboxylic acid] exhibited the highest antidiabetic activity.

From this study, it may be concluded that the 1,2,3,4-tetrahydro-9H-pyrido[3,4-b]indole-3-carboxylic acid compounds can be potentially be developed into useful antidiabetic agents that can prompt future researchers to synthesize a series of 1,2,3,4-tetrahydro-9H-pyrido[3,4-b] indole-3-carboxylic acid derivatives containing a wide variety of substituents with the aim of obtaining novel compounds with enhanced activity.

\section{REFERENCES}

1. Zimmet P, Alberti K, Shaw J. Global and societal implications of the diabetes epidemic. Nature 2001;414:782-7.

2. Dong C. Prevalence and prevention of type II diabetes. Nutr Metab (Lond) 2005;2:29-41.

3. Laakso M. Hyperglycemia and cardiovascular disease in type 2 diabetes. Diabetes 1999;48:937-42.

4. Burge MR, Sood V, Shobay TA, Rassam AG, Schade DS. Sulphonylurea induced hypoglycemia in type 2 diabetes mellitus. Diabetes Obes Metab
1999;1:199-206.

5. Momose Y, Maekawa T, Yamano T, Kawada M, Odaka M, Ikeda H, et al. Novel 5-Substituted 2,4-Thiazolidinedione and 4-Oxazolidinedione Derivatives as Insulin Sensitizers with Antidiabetic activities. J Med Chem 2002;45:1518-34.

6. Ferre P. Biology of peroxisome proliferator-activated receptors relationship with lipid metabolism and insulin sensitivity. Diabetes 2004;53:S43-50.

7. Wilson TM, Brown PJ. Sterenbatch DD, Henke BR. The PPARs: From orphan receptors to drug discovery. J Med Chem 2000;43:527-37.

8. Hannele YJ. Thiazolidinediones. New Eng J Med 2004;351:1006-9.

9. Smith MT. Mechanisms of troglitazone hepatotoxicity. Chem Res Toxicol 2003;16:679-87.

10. Gillies PS, Dunn CJ. Pioglitazone new drug profile. Drug 2000;60:333-43.

11. Buckle DR, Cantello BC, Cawthorne MA, Coyle PJ, Dean DK, Faller A, et al. Non Thiazolidinedione Antihyperglycemic Agents. 1: $\alpha$-Heteroatom Substituted $\beta$-Phenylpropanoic Acids. Bioorg Med Chem Lett 1996;6: 2121-6.

12. Buckle DR, Cantello BC, Cawthorne MA, Coyle PJ, Dean DK, Faller A, et al. Non Thiazolidinedione Antihyperglycemic Agents. 2: $\alpha$-Carbon Substituted $\beta$-Phenylpropanoic Acids. Bioorg Med Chem Lett 1996;6:2127-30.

13. Henke BR. Peroxisome Proliferator-Activated Receptor $\alpha / \gamma$ Dual Agonists for the Treatment of Type 2 Diabetes. J Med Chem 2004;47:4118-27.

Cite this article as: Choudhary AN, Kohli MS, Kumar A, Joshi A. Synthesis of tryptoline-3-carboxylic acid derivatives a novel antidiabetic agent. J Young Pharmacists 2011;3:132-7.

Source of Support: Nil, Conflict of Interest: None declared.

\section{New features on the journal's website}

Optimized content for mobile and hand-held devices

HTML pages have been optimized of mobile and other hand-held devices (such as iPad, Kindle, iPod) for faster browsing speed.

Click on [Mobile Full text] from Table of Contents page.

This is simple HTML version for faster download on mobiles (if viewed on desktop, it will be automatically redirected to full HTML version)

\section{E-Pub for hand-held devices}

EPUB is an open e-book standard recommended by The International Digital Publishing Forum which is designed for reflowable content i.e. the text display can be optimized for a particular display device.

Click on [EPub] from Table of Contents page.

There are various e-Pub readers such as for Windows: Digital Editions, OS X: Calibre/Bookworm, iPhone/iPod Touch/iPad: Stanza, and Linux: Calibre/Bookworm.

\section{E-Book for desktop}

One can also see the entire issue as printed here in a 'flip book' version on desktops.

Links are available from Current Issue as well as Archives pages.

Click on View as eBook 